\title{
The effect of heat stress on the activity of A1 and A2 neurosecretory neurons of Morimus funereus (Coleoptera: Cerambycidae) larvae
}

\author{
SNežana LEKOVIĆ, Jelica LAZAREVIĆ, Vera NENADOVIĆ and JelisaVETa IVANOVIĆ* \\ Institute for Biological Research "Siniša Stanković", 29 Novembra 142, 11060 Belgrade, Yugoslavia
}

Key words. Heat stress, protocerebrum medial neurosecretory neurons, midgut amylase, midgut protease, Morimus funereus, Cerambycidae, 5th larval instar

\begin{abstract}
A study on the effect of heat stress on the activity of the medial A1 and A2 neurosecretory neurons (NSN), and the activity of midgut a-amylase and protease was performed on the fifth larval instar of Morimus funereus. Exposure of the larvae to $35^{\circ} \mathrm{C}$ led to a decrease in the activity of both A1 and A2 NSN, the former being more marked than the latter. These neurons responded differently to heat stress in terms of neurosecretory material synthesis and release. The changes in the size of both A1 NSN and their nuclei and protease activity in the larvae exposed to elevated temperature were significantly correlated, which suggests that A1 NSN play a role in the regulation of the activity of this enzyme during heat stress. The significant correlations between the size of A2 NSN and protease activity in the controls, and the size of both A2 NSN and their nuclei and amylase activity in larvae exposed to heat stress, similarly may mean that A2 NSN regulate both digestive enzyme activities depending on environmental temperature.
\end{abstract}

\section{INTRODUCTION}

Temperature is one of the most important environmental factors affecting the performance and ecological distribution of organisms. High temperatures affect mortality, body size (Alpatov, 1930; Ochieng-Odero, 1992; Matsuki et al., 1994), flight ability (Shirai, 1993), oxygen consumption (Gray et al., 1991), juvenile hormone synthesis (Cusson et al., 1990), and the activities of digestive enzymes (Applebaum et al., 1964; Ivanović et al., 1975a, b), glycogen phosphorylase (Chen \& Denlinger, 1990), glycolytic enzymes and the respiratory chain and detoxification enzymes (Burnell et al., 1991). Elevated temperatures also disrupt the capability of insects to regulate water and $\mathrm{Cl}^{-}$ions (Colburn, 1983) and their tolerance to other stressors (Riskallan, 1984; DaLage et al., 1988).

High temperature disturbs the synthesis and release of neurosecretory material (NSM) from neurosecretory neurons (NSN), and thus the hormonal equilibrium to a greater or lesser extent (Wiglesworth, 1952), which can interrupt or even stop development and metamorphosis (O'Kasha, 1964).

Studies on acclimatization and acclimation in Morimus funereus larvae revealed seasonal changes in the activity of some digestive enzymes (protease and amylase), thermoresistance, haemolymph ion and trehalose concentration, qualitative and quantitative free amino acid composition and the level of glycogen in the fat body (Ivanović, 1969; Ivanović et al., 1975a; Ivanović \& Janković-Hladni, 1991; Janković-Hladni et al., 1992). These studies included investigations of the changes in protocerebral NSN activity based on cytological parameters, and showed an interrelationship between the changes in some NSN of the medial group and in the proteolytic and amylolytic activity in the midgut of the larvae.

The control of the activity of the digestive enzymes in insects has been little studied, although it is generally accepted that hormones play a dominant role in protein metabolism, i.e. in the synthesis of digestive enzymes. Indirect evidences suggest that the digestive enzyme activity in $M$. funereus larvae is under neurohormonal regulation (Ivanović et al., 1978; Ivanović et al., 1998). The aim of this study is to compare changes in protocerebral NSN and in digestive enzyme activity in larvae subjected to heat stress. In addition, the possible role of the different morphological types or subtypes of neurosecretory neurons in the synthesis of neurohormones that regulate proteolytic and amylolytic activities in $M$. funereus larvae was determined.

\section{MATERIAL AND METHODS}

\section{Experimental animals}

Adult specimens of $M$. funereus (Coleoptera: Cerambycidae) collected from oak trees growing in a mixed deciduous forest on Fruška Gora Mt. were placed in separate cages for mating and egg laying and kept in a chamber at $23^{\circ} \mathrm{C}$. In order to accurately determine each larval instar, the larvae were reared individually under controlled conditions on an artificial diet used for rearing Drosophila (Roberts, 1986), at a constant temperature of $23^{\circ} \mathrm{C}$, relative humidity of $70 \%$ and in the dark. Under these conditions, the fifth larval instar lasts for 15 days.

Seven day old 5th instar larvae, which had been reared at $23^{\circ} \mathrm{C}$, were divided into three groups each consisting of five individuals: (a) larvae kept at $23^{\circ} \mathrm{C}$ for 15 days (control); (b) those kept initially at $23^{\circ} \mathrm{C}$ then exposed to $35^{\circ} \mathrm{C}$ from day 7 to 15 and (c) those kept initially at $23^{\circ} \mathrm{C}$ and then exposed to $35^{\circ} \mathrm{C}$ from day 7 to 11 and then transfered to $23^{\circ} \mathrm{C}$ for 4 days.

All larvae were killed at 8 a.m.

\footnotetext{
* Corresponding author: e-mail: jeliva@ibbi.ibiss.bg.ac.yu
} 
The activity of type A (A1 and A2) medial neurosecretory neurons (NSN)

The medial group of neurons in the protocerebrum, located in the pars intercerebralis of the larvae, include chrom hematoxylin- and paraldehyde fuchsin-positive peptidergic type A neurons. Based on morphological (neuron size, cytoplasm to nucleus ratio, number of nucleoli, granule size and distribution) and histochemical characteristics, type A neurons can be divided into two subtypes, termed A1 and A2 (Scharrer and Weitzman, 1970; Panov, 1980; Ivanović et al., 1980; Nenadović, 1992).

In order to analyse protocerebral NSN activity the head capsules of the larvae were fixed in Bouin's fixative. After rinsing and dehydration, the tissue was immersed in paraffin (MERCK, $59^{\circ} \mathrm{C}$ ). Serial cross sections ( $5 \mu \mathrm{m}$ thick) were stained using the Alcian Blue, Pass, Orange-G technique (Herlant-Meewis, 1966).

The activity of the protocerebral medial NSN was estimated using the following cytological parameters:

the size of the protocerebral neurosecretory neurons, expressed as the mean of the products of the largest and smallest diameters of each neuron $(a \times b)$;

the size of the nucleus, expressed as the mean of the products of the largest and smallest diameter of each nucleus $(a \times b)$;

amount of neurosecretory material (NSM) was arbitrarily estimated as spare, present and abundant;

similarly, the NSM was described as either powdery, fine, medium or large grained.

Changes in these parameters were used to indicate changes in the activity of neurons.

The sizes of the neurons and nuclei were determined using a Leica QWIN program and the results expressed in $\mu \mathrm{m}^{2}$.

\section{Statistical methods}

All numerical data are presented as means \pm SEM. The means were obtained by measuring $275 \mathrm{~A} 1$ and $190 \mathrm{~A} 2 \mathrm{NSN}$. The significance of the differences between the control $\left(23^{\circ} \mathrm{C}\right)$ and the group exposed to $35^{\circ} \mathrm{C}$ was evaluated by means of a Student's t-test.

Numerical values for the activity of digestive enzymes previously reported by Ivanović et al. (1992) were correlated with Al and A2 NSN activity. Pearson's product moment correlation coefficients for the relationships between digestive enzyme activity (protease and amylase) and the activity of medial NSN (size of A1 and A2 medial NSN and the nucleus) were calculated for each of the temperatures (Sokal \& Rohlf, 1981).

\section{RESULTS}

\section{A1 neurosecretory neurons}

Larvae reared at $23^{\circ} \mathrm{C}$ showed cyclic changes in the size of A1 NSN 7 and 8 days after moulting. The maximum size was recorded in the evening of day 7 after which they decreased in size (Fig. 1). The size of nuclei first increased and then within $24 \mathrm{~h}$ returned to the control value and remained constant for the remainder of the period (Fig. 1). The amount and size of the NSM granules in the cytoplasm also changed (Fig. 2) and accompanied the changes in the size of both the neurons and the nuclei. This indicates cyclical changes between days 7 and 9 in the activity of A1 NSN at $23^{\circ} \mathrm{C}$.

The neurons and their nuclei had already achieved their maximum size after $6 \mathrm{~h}$ of exposure to constant temperature of $35^{\circ} \mathrm{C}$ (Fig. 1). The size of the nuclei, and the size and amount of NSM granules (Fig. 2) clearly indicate an

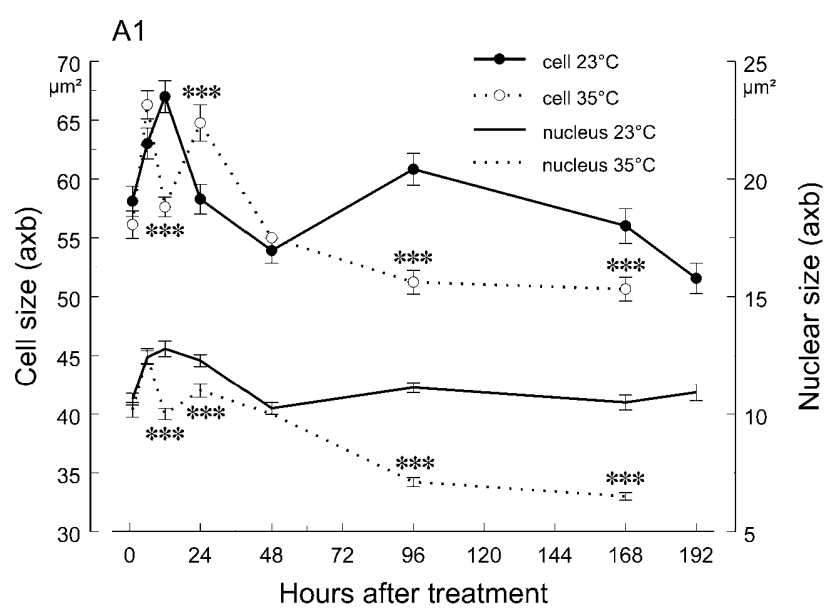

Fig. 1. Heat stress-related changes in the A1 NSN and nuclear sizes in $M$. funereus during the fifth instar. Significance of the differences was determined by the Student's t-test (**** $\mathrm{P}<$ 0.001 ).

increased synthesis and decreased NSM release after 12hour-exposure to $35^{\circ} \mathrm{C}$. Prolonged exposure to this temperature led to a significant reduction in the diameter of A1 NSN, and that of their nuclei, and a decrease in activity compared with the same neurons in the control larvae. However, after $48 \mathrm{~h}$ of exposure the larvae had similar sized A1 NSN to the controls. The most con-

\section{$\mathrm{A} 123^{\circ} \mathrm{C}$}

$\%$
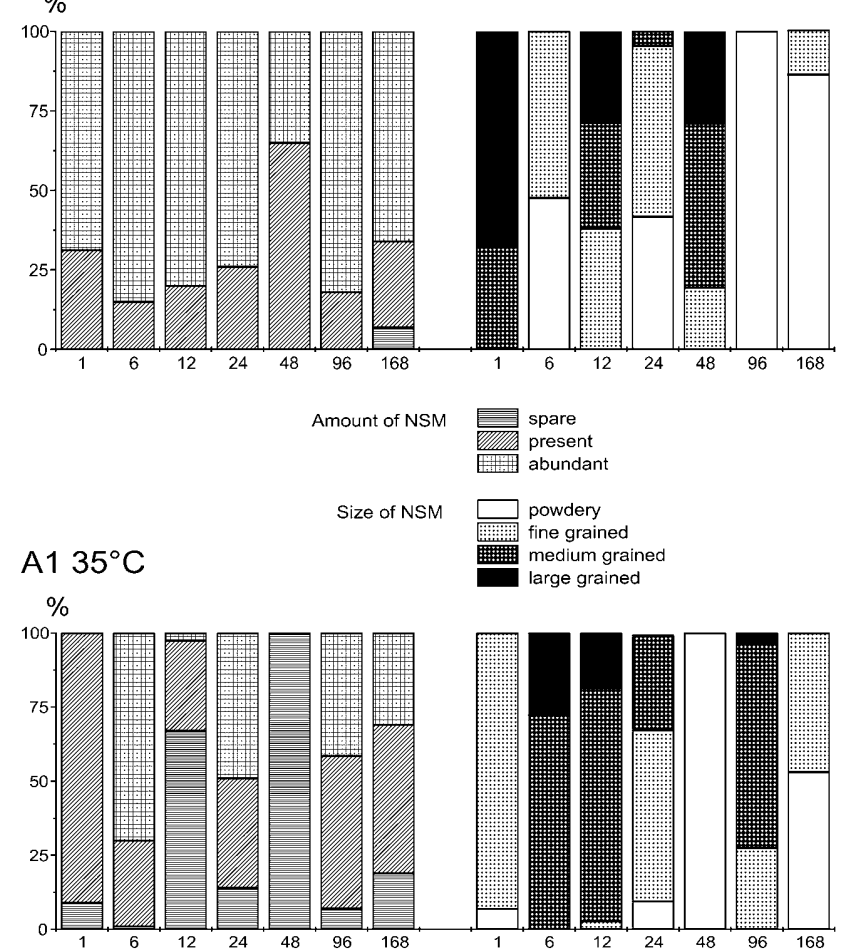

Hours after treatment

Fig. 2. Relative amount and size of neurosecretory material (NSM) in A1 neurosecretory neurons in the fifth instar larvae exposed to heat stress of $35^{\circ} \mathrm{C}$. Control values were taken as $100 \%$. 
TABLE 1. Correlation between activity of digestive enzymes and cytological parameters of A1 and A2 NSN of $M$. funereus larvae from day 7 to 15 in the fifth instar at $23^{\circ} \mathrm{C}$ and $35^{\circ} \mathrm{C}$. SNA1, SNA2 - the size of the A1 and A2 neurosecretory neurons and $\mathrm{SnA} 1, \mathrm{SnA} 2$ - the size of their nuclei. PA - proteolytic activity per mg midgut tissue; SPA - specific proteolytic activity per mg protein; AA - amylolytic and SAA - specific amylolytic activity.

\begin{tabular}{cccccc}
\hline $\mathrm{T}$ & $\begin{array}{c}\text { Enzym. } \\
\text { activity }\end{array}$ & SNA1 & SnA1 & \multicolumn{1}{c}{ SNA2 } & SnA2 \\
\hline $23^{\circ}$ & PA & 0.118 & -0.288 & 0.283 & $-0.468 @$ \\
& SPA & -0.077 & -0.192 & $0.668^{* *}$ & 0.144 \\
& AA & -0.118 & -0.005 & $-0.406 @$ & -0.334 \\
& SAA & -0.079 & 0.131 & $-0.429 @$ & -0.181 \\
$35^{\circ}$ & PA & $0.437 @$ & $0.721^{* * *}$ & 0.319 & -0.029 \\
& SPA & $0.481^{*}$ & $0.718^{* * *}$ & 0.403 & 0.163 \\
& AA & 0.187 & 0.006 & $0.625^{*}$ & $0.662^{* *}$ \\
& SAA & 0.093 & -0.092 & $0.472 @$ & $0.603^{*}$ \\
\hline
\end{tabular}

${ }^{\circledR} \mathrm{P}<0.1,{ }^{*} \mathrm{P}<0.05, * * \mathrm{P}<0.01, * * * \mathrm{P}<0.001$

Data recalculated from Ivanović et al. (1992)

spicuous decrease in NSM in these cells was recorded $48 \mathrm{~h}$ after the treatment

\section{A2 neurosecretory neurons}

The change in the nuclear size in $24 \mathrm{~h}$ was greater in the A2 NSN then in the A1 NSN in the control larvae (Fig. 3). A marked increase in the size of both the neurons and their nuclei was recorded in the morning of day 11 of the fifth instar, and was characterised by an increased amount of NSM consisting mainly of fine granules. Already after one hour of exposure to $35^{\circ} \mathrm{C}$ there was a reduction in the NSM followed by an increase after $6 \mathrm{~h}$ and a decrease after $12 \mathrm{~h}$. This might indicate an increased rate of synthesis and a decreased rate of release of NSM. After $192 \mathrm{~h}$ there was less NSM and in 50\% of the neurons the granules were very small (Fig. 4).

The effect of a constant high temperature of $35^{\circ} \mathrm{C}$ on the activity of A2 NSN was observed even during the first hour of exposure when there was a significant decrease in

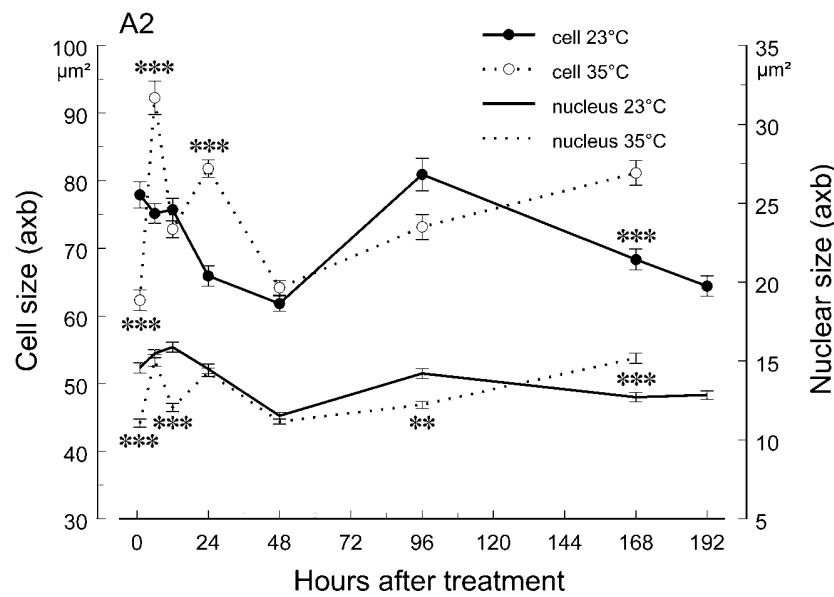

Fig. 3. Thermal stress-related changes in the size of A2 neurosecretory neurons and their nuclei in fifth instar larvae of $M$. funereus. Significant differences were determined using Student's t-test $\left(* * \mathrm{P}<0.01 ;{ }^{* * * * *} \mathrm{P}<0.001\right)$.
$\mathrm{A} 223^{\circ} \mathrm{C}$
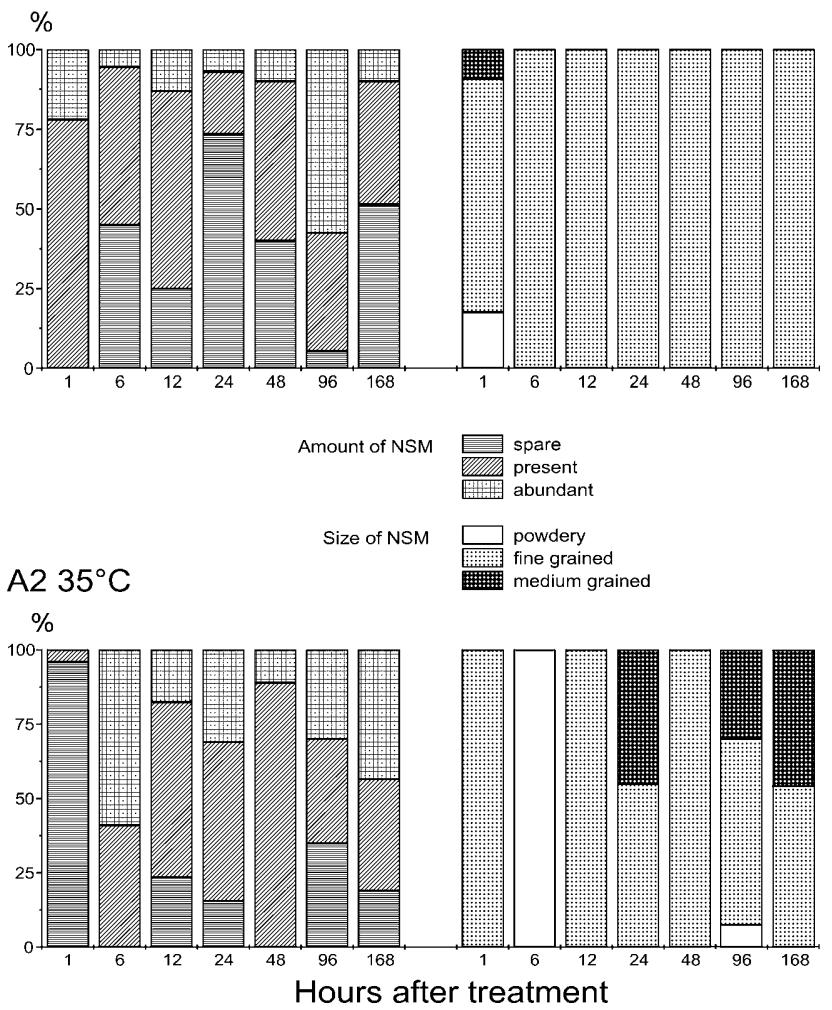

Fig. 4. Time course of heat stress-induced changes in the amount and size of NSM in A2 NSN in the fifth instar. For details see caption to Fig. 2.

the diameter of A2 neurons and their nuclei, and the activity of these neurons was at the lowest recorded. After $6 \mathrm{~h}$ of exposure to $35^{\circ} \mathrm{C}$, the diameter of the neurons increased compared with the control larvae $(\mathrm{P}<0.001)$, and achieved their maximum size. The size of the nuclei followed the changes in the size of the neurons (Fig. 3 ). High temperature also influenced NSM composition. The amount of NSM increased during the first $6 \mathrm{~h}$ of exposure to $35^{\circ} \mathrm{C}$, and decreased after $12 \mathrm{~h}$. Initially, the NSM was powdery and later fine grained NSM prevailed (Fig. 4).

\section{The recovery of $M$. funereus larvae from heat stress}

Four days after the heat stress treatment the size of A2 NSN returned to the control level, whereas the A1 NSN was significantly smaller $(\mathrm{P}<0.001$ ) (Fig. 5). The sizes of A1 and A2 NSN nuclei were significantly smaller then those of the controls, with the reduction in size being more marked in A1 than in A2 NSN. In heat stressed larvae, the release of NSM from A1 NSN was more marked than in control larvae. There was less NSM in A1 NSN of heat stressed larvae than in the controls particularly of large grain material (Fig. 6). A2 NSN were less active in releasing NSM than those of the controls. The amount of NSM was at the control level, but upon recovery there was more medium sized grain material than in the controls (Fig. 6). 


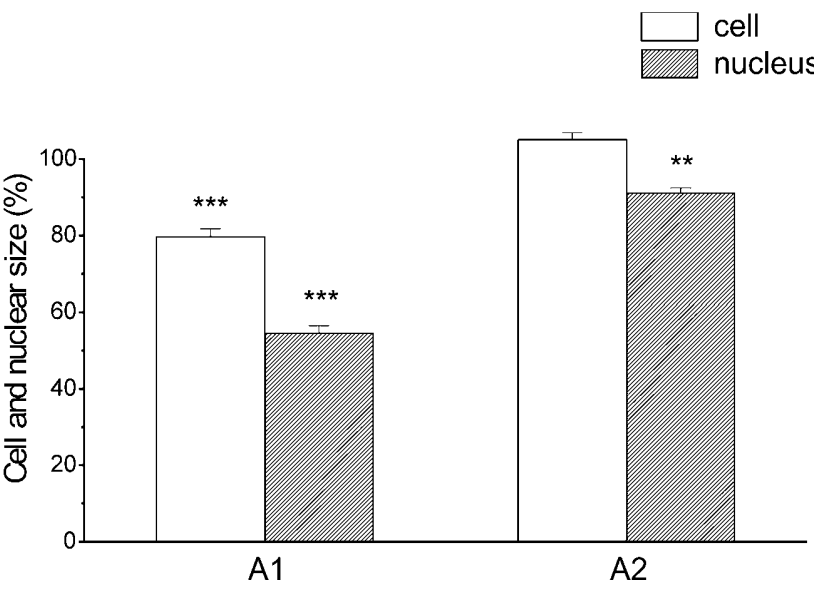

Fig. 5. Changes in the size of A1 and A2 NSN and their nuclei in $M$. funereus larvae during the recovery period. The values are expressed in relation to the corresponding control values taken as $100 \%$. The significance of the differences was determined using Student's t-test $\left({ }^{* *} \mathrm{P}<0.01 ; * * * \mathrm{P}<0.001\right)$.

\section{Correlation between cytological parameters and the activity of digestive enzymes}

At $23^{\circ} \mathrm{C}$ there were no significant correlations between the activity of digestive enzymes and the size of either A1 NSN or their nuclei (Table 1). In the heat stressed larvae, there was a significant positive correlation between SPA, and the size of A1 NSN and their nuclei (Table 1).

In the heat stressed larvae there were significant positive correlations between the size of both A2 NSN and their nuclei, and amylase activity (AA). Such correlations were not recorded in the control group, which showed a significant positive correlation between SPA and the size of A2 NSN (Table 1).

\section{DISCUSSION}

This comparative study on the NSN and the activity of the digestive enzymes in xylophagous $M$. funereus larvae demonstrates that heat stress $\left(35^{\circ} \mathrm{C}\right)$ results in changes in both NSN activity and activity of the mesenteric proteases and amylase. Our earlier study showed that heat stress adversely affected the survival and moulting of fifth instar M. funereus larvae (Ivanović et al., 1992).

The changes in the activity of A1 and A2 NSN in the protocerebrum medial group in $M$. funereus larvae showed that these cells respond differently to heat stress in terms of NSM synthesis and release. This was especially pronounced in the group of the larvae, exposed to heat stress for a short time and then returned to $23^{\circ} \mathrm{C}$. The fact that high temperatures affect permeability and activity of the membrane proteins might explain the differences in response of the NSN to heat stress, which is probably connected with differences in the physiological functions of these neurons.

Stress-related changes in digestive enzyme activity were accompanied by changes in the activity of NSN. Parallel changes in the activity of the medial NSN and in the activity of digestive enzymes were observed in an earlier study on $M$. funereus larvae exposed to low temperature $\left(-1^{\circ} \mathrm{C}\right.$; Ivanović et al., 1975b). Ivanović et al. (1980) observed parallel changes in the activity of A1 NSN and protease activity and proposed that $\mathrm{A} 1$ and $\mathrm{A} 2 \mathrm{NSN}$ have different physiological roles. At $-1{ }^{\circ} \mathrm{C}$ there is a simultaneous decline in protease activity and increase in amylase activity with decrease in A1 and increase in A2 NSN activity.

On the basis of the correlation coefficients obtained it can be assumed that A2 NSN have two physiological functions: the regulation of protease activity at $23^{\circ} \mathrm{C}$,
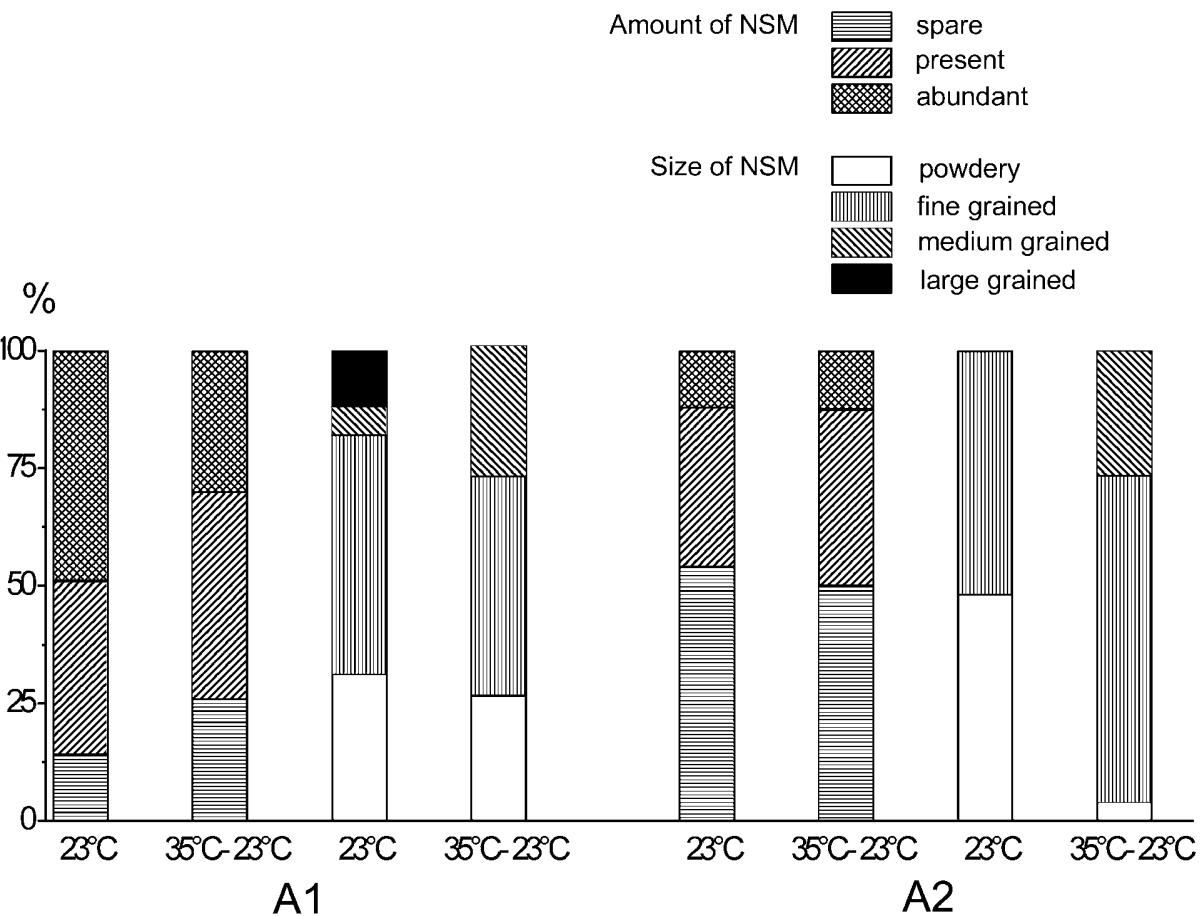

Fig. 6. The size and amount of NSM in A1 and A2 NSN during recovery after a four day exposure of M. funereus larvae to heat stress. 
indicated by significant correlation between SPA and SNA2, and the regulation of amylase activity at $35^{\circ} \mathrm{C}$, indicated by significant correlation between SAA and $\mathrm{SnA2}$. It is worth mentioning that the protein content of the mesenteron is not correlated with proteolytic activity in the larvae kept at either $23^{\circ} \mathrm{C}$ or $35^{\circ} \mathrm{C}$ (Stamenović, 1995), which indicates that secretagogue mechanism does not contral proteolytic activity. This finding, together with other indirect evidence, corroborates the aforementioned working hypothesis on hormonal regulation of digestive enzyme activity in the larvae of this species (Ivanović et al., 1978; 1998). The inability of A2 NSN to recover their activity after heat stress might explain why amylase activity does not recover (Ivanović et al., 1992). The double function of A2 NSN may be achieved through the synthesis of different neurohormones in response to varying environmental conditions. The possibility that one neuron might synthesize different neurohormones has been reported for other insect species (Homberg et al., 1991; Goltzene et al., 1992; Dai et al., 1994). The fact that over 50 neurohormones have been identified, whereas the number of morphologically different NSN in insects is much lower, supports the above hypothesis.

In addition to this interpretation, the possibility that different amounts of the same hormone are released at different temperatures should not be ruled out. For example, in the experiments in which the extracts were prepared from different number of the cerebral complexes (CC, cerebrum + corpora cardiaca) of active donors and given to ligated $M$. funereus larvae, the dose-dependent curves of protease and amylase activity were almost linear but divergent in relation to $\mathrm{CC}$ concentration in the extracts. Maximum a-amylase activity was observed when the larvae received the extract containing half of the $\mathrm{CC}$ in 10 $\mu \mathrm{L}$ saline, while maximum protease activity was achieved when larvae were injected with the extracts containing 3CC in $10 \mu \mathrm{L}$ saline (Ivanović et al., 1998). Further study along these lines is in progress.

ACKNOWLEDGEMENTS. The authors are greatly indebted to J. Joksimović, Institute for Biological Research "Siniša Stanković", Belgrade. This work was supported by the Ministry for Science and Technology of Serbia, grant $\# 03$ E13.

\section{REFERENCES}

Alpatov W.W. 1930: Phenotypical variation in body and cell size of Drosophila melanogaster. Biol. Bull. 58: 85-103.

Applebaum S., Janković M., Grozdanović J. \& MarinKović D. 1964: Compensation for temperature in digestive metabolism of Tenebrio molitor larvae. Physiol. Zool. 34: 90-96.

Burnell A.M., Reaper C. \& Doherty J. 1991: The effect of acclimation temperature on enzyme activity in Drosophila melanogaster. Comp. Biochem. Physiol. 98B: 609-614.

Chen C.P. \& Denlinger D.L. 1990: Activation of phosphorylase in response to cold and heat stress in the flesh fly Sarcophaga crassipalpis. J. Insect Physiol. 36: 549-553.

ColbuRn E.A. 1983: Effect of elevated temperature on osmotic and ionic regulation in a salt-tolerant caddisfly from Death Valley, California. J. Insect Physiol. 29: 363-369.

Cusson M., McNiel J.N. \& ToBe S.S. 1990: In vitro biosynthesis of juvenile hormone by corpora allata of Pseudaletia unipuncta virgin females as a function of age, enviromental conditions, calling behavior and ovarian development. $J$. Insect Physiol. 36: 139-146.

Dai J.-D., Mizoguchi A. \& Lawrence G.I. 1994: Immunoreactivity of neurosecretory granules in the brain-retrocerebral complex of Manduca sexta to heterologous antibodies against Bombyx prothoracicotropic hormone and bombyxin. Invertebr. Reprod. Dev. 26: 187-196.

DaLage J.L, CaPY P. \& DAVID J.R. 1988: Starvation and desiccation tolerance in Drosophila melanogaster adults: effects of enviromental temperature. J. Insect Physiol. 35: 453-457.

Gray D.R., Logan J.A., Ravlin F.W. \& Carlson J.A. 1991: Toward a model of gypsy moth egg phenology: using respiration rates of individual eggs to deternine temperature-time requirements of prediapause development. Envir. Entomol. 20: $1645-1652$

Goltzene F., Holder F., Charlet M., Meister M. \& Oka T. 1992: Immunocytochemical localization of Bombyx PTTHlike molecules in neurosecretory cells of the brain of the migratory locust, Locusta migratoria: A comparison with neuroparsin and insulin related peptide. Cell Tiss. Res. 269: $133-140$.

Herlant-Meewis H. 1966: Les cellules neurosecretrices de la chaine nerveise d' Eisenia foetida. Z. Zellforsch 69: 319-325.

Homberg U., Davis N.P. \& Hicdebrand J.G. 1991: Peptide immunocytochemistry of neurosecretory cells in the brain and retrocerebral complex of the sphinx moth Manduca sexta. $J$. Comp. Neurol. 303: 35-52.

IvaNović J. 1969: Changements saisonniers d'activite et de thermoresistance de l'amylase intestinale des larves xylophages de l'espece Morimus funereus L. Matica Srpska. Zb. prir. nauke 36: 155-161 (in Serbian).

IVANović J., JanKović-HLADNI M. \& Milanović M. 1975a: Effect of constant temperature on survival rate, neurosecretion and endocrine cells and digestive enzymes in Morimus funereus larvae (Cerambycidae:Coleoptera). Comp. Biochem. Physiol. 50A: $125-130$.

IVANOVIĆ J.P., Janković-HladnI M.I. \& Milanović M.P. 1975b: Possible role of neurosecretory cells type A in response of Morimus funereus larvae to the effect of temperature. $J$. Therm. Biol. 1: 53-57.

Ivanović J., Janković-Hladni M., Stanić V., Nenadović V. \& Milanović M. 1978: Midgut of coleopteran larvae the possible target organ for the action of neurohormones. In Bargmann W., Oksche A., Polenov A.L. \& Scharrer B. (eds): Neurosecretion and Neuroendocrine Activity - Evolution, Structure and Function. Springer Verlag, Berlin, pp. 373-376.

IVanović J., Janković M., Stanić V. \& Milanović M. 1980: The role of the cerebral neurosecretory system of Morimus funereus larvae (Insecta) in thermal stress. Bull. T. LXXII Acad. Serbe Sci. Arts Classe Sci. Nat. Math. Sci. Nat. 20: 91-97.

Ivanović J. \& JanKović-HLADNI M. 1991: Hormones and Metabolism in Insect Stress. CRC Press, Boca Raton, 178 pp.

Ivanović J., Janković-Hladni M., Đormević S., Stamenović S. \& LAZAREVIĆ J. 1992: The effect of high temperature on metabolism of Morimus funereus larvae during an intermoult period. J. Insect Physiol. 38: 877-883.

IVANović J., Lazarević J., ĐorĐeVić S., LeKović S. \& Nenadović V. 1998: Influence of diet composition and neurohormones on digestive enzyme activities in Morimus funereus larvae. Acta Entomol. Serb. 3: 101-107.

Janković-Hladn M., Chen C.A., Ivanović J., ĐorĐević S., Stanić V., Perrć V. \& Frušić M. 1992: Effects of diet and temperature on Morimus funereus larval hemolymph cation concentrations. Arch. Insect Biochem. Physiol. 20: 205-214. 
Matsuki M., Ayres M.P. \& MacLean S.F., JR. 1994: Temperature effects on growth and molt of Nematus calais (Hymenoptera: Tenthredinidae). Physiol. Chem. Ecol. 23: 719-725.

O'Kasha A.Y.K. 1964: Effect of high temperature on Rhodnius prolixus (Stal). Nature (London) 204: 1221-1222.

OChiEnG-Odero J.R.P. 1992: The effect of three constant temperatures on larval critical weight, latent feeding period, larval maximal weight and fecundity of Cnephasia jactatana (Walker) (Lepidoptera: Tortricidae). J. Insect Physiol. 38: $127-130$.

NenAdović V. 1992: Differentiation of protocerebral neurosecretory system during postembryonal development of Morimus funereus (Col. Cerambycidae). Ph. D. Thesis, University of Novi Sad, Novi Sad, 146 pp.

Panov A.A. 1980: Demonstration of neurosecretory cells in the insect central nervous system. In Strausfeld N.J \& Miller T.A. (eds): Neuroanatomical Techniques. Insect Nervous System. Springer-Verlag, New York, Heidelberg, Berlin, pp. 25-50.

RoBerts D.B. 1986: Drosophila: A Practical Approach. IRL Press, Oxford, pp. 15-19.
RISKALLAN M.R. 1984: Influence of posttreatment temperature on the toxicity of pyrethroid insecticides to susceptible and resistant larvae of the Egyptian cotton leafworm Spodoptera littoralis (Boisd.). Experientia 40: 188-190.

Scharrer B. \& Weitzman M. 1970: Current problems in invertebrate neurosecretion. In Bargmann W. \& Scharrer B. (eds): Aspects of Neuroendocrinology. Springer-Verlag, Berlin, Heidelberg, New York, pp. 1-23.

SHIRAI Y. 1993: Factors influencing flight ability of male adults of the diamondback moth Plutella xylostella, with special reference to temperature conditions during larval stage. Appl. Entomol. Zool. 28: 291-301.

SoKal R.R. \& Rohlf F.J. 1981: Biometry. San Francisco, Freeman, pp. 859 pp.

StAMENOVIĆ S. 1995: The effect of constant high temperature $\left(35^{\circ} \mathrm{C}\right)$ on the neuroendocrine system and metabolism of larvae Morimus funereus (Coleoptera, Insecta). M.S. Thesis, University of Belgrade, Belgrade, $108 \mathrm{pp}$.

WigGLESWORTH V.B. 1952: Hormone balance and the control of metamorphosis in Rhodnius prolixus (Hemiptera). J. Exp. Biol. 29: 620-631.

Received November 10, 1999; revised May 12, 2000; accepted July 10, 2000 